\title{
The Protagonists Break the Tyranny of Silence- A Comparative Study on Margaret Atwood's The Handmaid's Tale and Shashi Deshpande's That Long Silence
}

\author{
S.Sarkunam \\ Ph.D. Scholar \\ Department of English and Research Centre, Seethalakshmi Achi College for Women, Pallathur, \\ Sivagangai District, Tamilnadu, India

\section{Dr. Sheila Royappa} \\ Associate Professor of English \\ Department of English and Research Centre, Seethalakshmi Achi College for Women, Pallathur, \\ Sivagangai District, Tamilnadu, India
}

\begin{abstract}
The wide variety of literatures in both the countries Canada and India - nurture the growth of a unique identity in each case. Like India's own complex literary heritage, Canadian literature is written in more than one language. It reflects a regionally diverse and multicultural society. Its citizens come from every corner of the globe who retain their own distinctive heritage. Similarly Indian - English literature undeniably is today one of the many modern Indian literatures. The difference between the other Indian literatures and this branch is that other literatures have well-defined communities of readers who speak those languages as their primary languages. The majority of readers of Indian - English literature within India use English as their secondary language.
\end{abstract}

Keywords: Comparative Study, Subjugation, Financial Independence, Individuality, Identity

\section{INTRODUCTION}

The comparative method of studying a piece of work involves great scope. In spite of the individual characteristics of a work when compared it takes a new garb and enlightens the readers. Margaret Atwood's The Handmaid's Tale and Shashi Deshpande's That Long Silence are the two novels taken for a comparative study. Both novels deal with the different barriers that enwrap woman. It is a record of the oppression of the protagonist's individuality by curbing her liberty of thought, action and speech.

\subsection{Text}

Margaret Atwood is Canada's most eminent novelist, poet and critic. The Handmaid's Tale has won both the Arthur C. Clarke Award for Science fiction and the Governor General's Award. She lives in Toronto with the writer Graeme Gibson and their daughter. Shasi Deshpande one of the eminent writers in Indian English literature was born in Dharwad. She was the recipient of the Sahitya Academi Award (1990) for her novel That Long Silence. She lives in Bangalore with her pathologist husband and her two sons.

In That Long Silence Shasi Deshpande delineates the delicate Swings of mood, the moments of joy and despair of the narrator protagonist Jaya - a housewife and a failed writer. The consciousness of Jaya is revealed through an exposition of her mind in the process of thinking feeling and reacting to the stimuli of the moment and situation.

Margaret Atwood's The Handmaid's Tale narrates the tale of quasi-military Republic (Gilead) that chiefly concentrates on human reproduction. She presents a modern form of woman hunting that aims at subjugating woman's power that is her fertility. Atwood a sensitive and consciously self-aware writer explores and expresses the subjugation of women in a patriarchal society. She believes that the silencing of woman and victimization is not only through patriarchal attitudes but also through 
woman's consciousness. People who are after power cannot tolerate imagination, power to communicate and hope. In order to combat it, one should recognize the source of oppression, express anger and find ways for change.

Offred and Jaya are denied the right to speak, communicate and express. They are even denied of their original names. Moreover they are assigned certain functions and are expected to perform different roles. The intention of this comparative study is to examine the protagonists' need for articulation of their suppressed silence.

The rulers of Gilead use religion to ensure the subjugation of women. The epigraph from Genesis 30:1-3 suggests the patriarchal scheme of creating a sense of unworthiness in women. It also pictures the complex nature of women in subordinating other Women and advocating self effacement. When Gilead first came into being, the very first step of the rulers had been to freeze women's credit cards and bank accounts, and take away their jobs and property rights. This results .in the destruction of their financial independence and individuality.

Similarly Jaya succumbs and Surrenders to Mohan without revolting. Silently she bends herself to his will. Enwrapped by silence in her room, her mind shuttles between the past and the present and thus covers the whole span of her life. Jaya is fighting her own battles. On the one hand, she has to tackle the immediate problems of a likely indictment of her husband on charges of corruption the other she wants to examine their relationship. So far it has been dominated by the will of Mohan. Even her career as a writer is in danger since he insists on her writing only "safe stuff" disallowing her earlier impassioned expressions. Now in his hour of need her help is taken for granted. Her teenage children also give her a sense of failure. Her son Rahul is extra-sensitive and already turned cynical. Her daughter Rati, is a spoilt girl totally materialistic. Jaya ponders: "I had shaped myself so resolutely to his desires all these years, yet what was I left with now ? Nothing. Just emptiness and silence" (LS 144).

In Gilead a deliberate and systematic attempt is made to obliterate all sense of individuality and identity in women by taking away the names from them. The state cancels the original names of the Handmaids in order to erase their former identity and labels them according to the names of their commanders. It is metaphoric of the silencing of women

Offred's name is composed of the preposition Of indicating possession and 'Fred' signifying that she is the Handmaid of Fred Offired says, "My name isn't Offired. I have another name, which nobody uses now because it is forbidden... name is like your telephone number, useful only to others" (HT 79-80). Ofwarren and Ofglen are also re-named indicating that they are the material possession of Warren and Glen respectively.

Like Offred, Jaya too loses her identity and has to forge a new identity and name suiting her husband's desire. Jaya has to fight out fragmentation of her individuality and also find a meaning if she can. Jaya means victory, Her husband calls her Suhasini meaning "a self smiling, placid motherly woman. A woman who lovingly nurtured her family. A woman who coped" (LS 15). Jaya is not like some modern women who are influenced by westegn ideas OAt the Same time, she is not a stereo type of a traditionalwoman who is confined to the hearth and to man. She does not want to be Sita, Savitri or Draupadi.

Both lose their identity individualism with the loss of their original name.Name is the only component that makes a person unique. With the loss of their names, they have lost their identity itself.

In The Handmaid's Tale, Gilead succeeds in reducing woman's perception of herself as a mere function. This promotes fragmentation. The women are divided into different classes according to their function and are identified with specific uniform. The house keepers (Marthas) wear green. The aunts (disciplinarians) are given army uniform. Working class (Eco wives) wear red, green and blue striped outfits. The Handmaids wear red gown with nunlike white head gears. They are cloistered but act like mistresses. Their clothes are specially designed to hide bodily contours and the wings and veils are means to prevent her "from seeing and also from living seen" (HT 18).

Thus they are alienated from their own bodies by the elaborate clothes that have to be worn by them at all time, covering them fully in many layers. Offred considers herself "a distorted shadow, a parody of something, some fairytale figures in Red cloak" (HT 19).

The State reduces the handmaids to the slavery status of being mere breeders. "We are two legged wombs, that's all: sacred vessels, ambulatory chalices" (HT 146). The handmaid must act as a 
surrogate mother and bear a child for the aging commander and his barren wife. The Biblical Rachel is their model. The handmaid is declared un woman if she fails to conceive. As a punishment she is banished to the colonies where women clean up radioactive waste as slave laborers. At the same time men are never associated with sterility. Offred comments, "There are only women who are fruitful and women who are barren, this is the law" (HT 57)

When Offred fails to conceive she experiences anguish and disappointment. Her mind is trained to think of herself only in connection with her womb. In other words only in the child-bearing context and regards herself as a failure when the function is not fulfilled. She prays, "Oh God Obliterate me. Make me fruitful. Mortify my flesh that I may be multiplied. Let me be fulfilled" (HT 204).

Unlike the Gileadean women, Jaya is not confined within one or two functions. She has multiple functions / roles to play. The individual in Jaya is in crisis on all fronts - as a mother, a wife, a sister, daughter and above all an Indian woman. Jaya is in search of happiness peace of mind. Apparently she has all but not the sense of belonging Her feminine dilemma is expressed in her vacillating state of mind, "I could and couldn't do, all the things that were womanly and unwomanly" (LS 33). Jaya is Suhasini and also "Seeta" the pseudonym she assumes to write columns about the plight of the middle class housewife. "Suhasini" and "Seeta" are as Jaya says: "The many selves waiting to be discovered............. each self attached like a Siamese twin to a self of another person, neither able to exist without the other" (LS 69).

She keeps on oscillating in opinions and choices. She leaves her comfortable Church Gate apartment and comes to stay in a small flat in Dadar for the sake of her husband. Away from the routine, she is confronted with difficult truths about her past. She tries to recall the fragments of her self-entangled in her memory. "Ours has been a delicately balanced relationship, so much so that we have even snipped off bits of ourselves to keep the scales on an even keel," (LS 70).

Mohan has clearly defined views about what a wife may do or may not do. He wanted his wife to be "Suhasini" and not Jaya. So Jaya tried to fit herself into Suhasini's image. At her father's home, Jaya had never restrained herself, instead she had let herself to as their quibbles had always exploded into laughter in which everybody including her father had joined. But Mohan had felt so hurt by her laughter that she dared not laugh in his presence. She gradually learnt that his mood was best met with silence.

She did not like these changes but considering them to be inconsequential, she did not mind them much. But what really upset her was the fact that in order not to damage her marriage, she did things, which she would otherwise be ashamed of doing. The fear of damaging her marriage made her behave absolutely inhuman. For instance she quietly left her neighbour Mr. Kamat's room while he was struggling to breathe his last, instead of attending to him, fearing it would hurt Mohan if the other neighbours gossiped about her presence in Kamat's room.

Offred too has such experience. There is constant invigilation to prevent the forging of relationships among women. Though Offred loves to "fraternize with the marthas she "realises that the patriarchal language has no "Corresponding word that meant to behave like sister'(HT 21). It banishes woman from such healthy relationship as they are fearful of "woman's power." Thus silence and powerlessness go together in the lives of Offred and other handmaids.

In Gilead, women are prohibited from communicating with one another. Offred and other handmaids are muted economically, emotionally and literally. They are forbidden to read and write as it is a man's prerogative. As they are denied self-expression through writing and speaking, they are isolated from the world around them. They try to keep in touch with the world through reading whenever possible and through a secret exchange of oral information with one another.

Similarly in the marital relationship between Jaya and Mohan, there is nothing seriously wrong outwardly. But there is hardly any communication between them verbal / emotional. Temperamental incompatibility between them accounts for their strange silence, Nothing. Nothing between us... nothing between me and Mohan. We live together, but there had been only emptiness between us" (LS 185).

As a writer she went to the extent of changing the very stuff she would have loved to write. Instead of writing about angry women, she wrote the soap opera Seeta stuff, which pleased Mohan. The reason is once when she had received award for one of her writings, Mohan instead of admiring her had felt 
hurt and sulked, thinking that his wife had exposed to the world their own relationship. He had been quite incapable of understanding how a writer can aptly transmute experience into artistic creation. As she wrote without emotion, in order to satisfy Mohan, her writings were rejected. As a result she was overcome by a sense of failure. All this made Jaya very restless. Like Offred, Jaya too is notable to express in the beginning. She too feels the suffocation and is shocked and outraged.

The 'Colonies are symbol of exploitation, isolation and alienation. The barriers that enwrap women in Gilead are many. They are denied of names, speech, and communication and are segregated according to their functions. Even the basic freedom to eat and bathe is re others. They are fed only with what the authorities regard as healthy food. Around her ovulation time on the night before the "Ceremony' Martha gives her a bath. After the bath she waits for the ceremony. Feeling completely dehumanized. "I wait, washed, brushed fed like a prize pig" (HT 79).

Their freedom is curtailed as they are spied. Guards are known as Guardians and Spies are renamed as Eyes. They spy on each other and everyone. Through Offred's comment on Ofglen her shopping companion "she is my spy as I am hers" (HT 29). Atwood pictures the mutually distrustful atmosphere in Gilead.

Freedom of speech is a capital offence. According to Offred language is officially forbidden because the ruling class recognizes the power of words as weapons that can free the people from bondage. They are denied books, paper and pens. Only the ruling class has access to books. For minor offences like reading, their arms and legs are chopped off as they are not essential for reproduction. The game of scrabble, a symbol of reading, writing and knowledge is a clandestine activity. "Now it's forbdden for us now it's dangerous. Now it's indecent" (HT 149). Thus words are forbidden in a society governed by Biblical words.

Jaya too faces such barriers. Her freedom is curtailed. The role of a wife curtails women's selfdevelopment. The role of a mother does it even more. A woman brought up in orthodox, traditional and rural background has to cope up4ith so many things. Shashi Deshpande's heroines like Jaya are rebels in a passive manner. Their voices are lost in wilderness. But Jaya transmutes her rebellion and suffering into an artistic expression In her there is an inner need for creativity This creative expression is stifled due to lack of having a 'room of her own'Social and family pressure stifles her creativity. It holds all creative activities in subservience to her role as a home maker. Jaya says everyone" (LS 97).

In the so-called ordeal called living, Jaya finds herself at odds with society and undergoes various degrees of psychological transformation. Her urges are silently manifested in moments of crisis and in "Chaotic sequence of events and non events" (LS 167) that made up her life. The reasons for silence are that "it was so much simpler to say nothing. So much less complicated" (LS 99).

Jaya's inner turn oils are so tense and acute that she is not able to express her troubles. She is a woman who faces the sufferings and opposition in the true spirit of ideal Hindu womanhood noted for obedience and loyalty. Jaya broods over the metaphor of the "Sheltering tree'. "A husband is like a sheltering tree...... without the tree, you are dangerously, Unprotected........and vulnerable..... have to keep the tree alive and flourishing, even if you have to water it with deceit and lies" (LS 32).

To Mohan, it is unwomanly to be angry. He says, "a woman can never be angry, she can only be neurotic, hysterical, frustrated. There is no room for despair, either. There is only order and routine, today I have to change the sheets tomorrow, scrub the bathrooms the day after, clean the fridge" (LS 147-148).

In total, Offred and Jaya are subjugated by patriarchal power structures. They have lost their names; they are reduced to mere functional elements. Communication is banned. Freedom is - curtailed Freedom to move, talk, express etc. They are reduced to the status of slave. They are debased and dehumanized. As a result they are alienated.

Gileadean women are alienated from their surroundings by the severe restriction on their freedom of movement. Offred's room is a transit camp a prison cell. The use of mirrors, glass window panes, hooks have been dispensed with for safety purpose and also for dispossessing women of her identity. Bells measure time here. They are also denied the opportunity to create.

Gilead's aim is the total annihilation of women as a person. Offred discovers that even the memory of her has been erased from her daughter's mind as if she had never existed. "I have obliterated for her......You can see it in her eyes, I am not there....... I can't bear it, to have been erased like that" (HT 240). 
Both Offred and Jaya find themselves a pawn in the hands of others. They have to bend according to the will of authorities / husband. When their basic rights to live a life as they love to is at stake, one can expect volcanic eruptions. This is what happens in both the cases. Through all barriers they break creating a new discourse against the chaos of thoughts.

The suppression of the legitimate natural voice, anticipates volcanic vibrations and eruption. Though Offred is initially silenced by Gileadean culture she eventually works her way to freedom through language. Despite the call of authority to forget, to be silent, Offred's response is defiant. Her scripting of the self through memory and language proclaims her triumph and the defeat of patriarchal schemes. Every action of Offred like having a physical relationship with Nick, every symbol like playing of the scrabble, every image like that of the wall, Square, Church, the hint of chosen words like 'Ceremony', 'Salvagings' demonstrates the skill of Atwood in breaking the barriers.

Jaya too is not a mute sufferer. She is perpetually probing and protecting her autonomy. Hers is a silent revolt. Silence seems to be her natural condition. When her husband, Mohan talks about women being treated very cruelly by their husbands which he calls strength, she bursts into rumination, "He saw strength in the woman sitting, silently in front of the fire, but I saw despair. I saw a despair so great that it would not voice itself. I saw a struggle so bitter that silence was the only weapon. Silence and surrender" (LS 36).

Both Offred and Jaya are shocked and consider such activities as barbarous. Offred feels her body no longer suited for pleasure. She fills her mind with nostalgic memories of her husband and daughter and strongly desires to escape from her present claustrophobic environment. The handmaids adopt various methods of escape from their intolerable oppression. Some choose suicide, others through physical flight. Some choose to indulge in rebellious and sabotage activities. Offred too decides to committ suicide, but she considers suicide an idle thing, a timid action.

Language has always been acknowledged as a powerful and perhaps the only weapon at the disposal of those under subjection. Offred and Jaya realise this. Offred is aware that the fruition of the survival wish is possible only through a communication with the outer world that is denied to her. She regrets "If only we could talk to them (Angels) something could be exchanged. we still had our bodies" (HT 13). The power of the body language is also seized from the handmaid, as they are segregated from the opposite sex. Despite being constantly warned against the evils of talking and advantages of silence, the handmaids communicate in different ways and defy the vigilant aunts. "We learned to whisper almost without sound. In the semi- darkness we could stretch our arms, when the aunts were not looking and touch each other's hands across space. We learned to lip-read........In this way we exchanged names from bed to bed: Alma, Janine, Dolores, Moria, June (HT 14). Their new code language is carried to the other with the movement of silent lips, looks, smiles, whistles and winks.

In Offred's room the previous occupant had stealthy scratched a coded message in a cupboard, "Nolite and bastardes carborundirum" (let not the bastards crush you). The language is foreign to her, yet the message is carried, "It pleases me to ponder this message. It pleases me to think that I am communicating with her......They give me a small joy" (HT 62). Though engulfed by restrictions, Offred communicates with the unknown inscriber and demolishes the barriers of death

Similarly Offred manages to communicate with her former friend Moira who also arrives at the same training centre. Later too Offred and Ofglen discover that they were both "non-believers'. Inspite of the ban on all communication between the handmaids and the Marthas, one of the housekeepers Cora, develops a liking for Offred. She is even willing to lie for her once. To Offred this step itself is a triumph in itself. "It pleased me that she was willing to lie for me, even in such a small thing, even for her own advantage. It was a link between us" (HT 160).

Offred's eagerness to look upon Serena Joy as an older sister or a motherly figure is shattered by her coldness in the beginning. But later for her own selfish needs she offers to help and arranges clandestine meetings between Offred and Nick. She further promises to get a photograph of Offred's daughter. Small gifts given by Serena and Rita, compliments showered on Rita by Offred are examples of the growing healthy relationship under rigid atmosphere. Women overcome the externally imposed interpersonal alienation and reach out to one another secretly.

Similarly in Jaya's case though life is full of choice, for a married woman the choices are limited. She has no choice left to her save what her husband wills and desires. Unlike other married women 
slavishly tagged to tradition, Jaya articulates in her own way. She unfurls and unburdens herself to activate the creative impulses Smothered within her artistic self. She unburdens her most personal and private thoughts in her writings This act of self expression becomes for her a creative process. Both Offred and Jaya gain confidence and break all the barriers.

Offred the powerless is empowered by her intellectual competence. Her communicatory skill becomes multi-dimensional. She begins to win the word game of scrabble. In return for clandestinely playing scrabble with her commander, Offred gets precious hand-lotion for her face and hands. But more valuable than that is the intangible gain that she is no longer just an object to him after that, "To him I'm no longer merely a usable body" (HT 172). She discovers that there can be freedom even within the prison. She is able to ask the commander questions, to criticize and even to condescend him. She gives him an insight into the real living conditions and situation of handmaids. She realises the power of pen. As she says, "The pen between my fingers is sensuous the alive almost, I can feel its power, the power of words it contains...Just holding it is envy, I envy the commander his pen. It's one more thing I would like to steal" (HT 196).

Offred lives through her memory. She creates a free space for herself in her flashbacks. She often recalls the views and actions of her mother. She recalls her life with her husband Luke and their daughter. She mourns a holistic love for them. "Nobody dies from lack of sex. It's lack of love..." (HT 113). In this way Offred endorses a genuine and holistic love for her husband and daughter. Offred apologizes for her frequent flashbacks, "You'll have to forgive me. I am a refuge from the past and like other refuges I go over the customs and habits of being. I've left or been forced to leave behind" (HT 239).

Jaya in the process of self-revelation through writing comes to recognize herself as a failed writer. Her stories had been rejected for lack of genuine feelings which she had laid aside for the sake of her husband. She had also kept away the clamouring voices of women who wanted to find expression; for fear that they may ruffle her domestic life. Her creative urge and artistic enthusiasm frees her from domestic and societal roles. It releases her from emotional and mental trauma. At last she is determined to break that long silence by putting down on paper all that she had suppressed in her seventeen years' silence - that long silence which had reduced her 'self to fragments, "I am not afraid any more. The panic has gone. I am Mohan's wife. I had thought and cut off the bits of me that refused to be Mohan's wife, now I know that kind of fragmentation is not possible. The child hands in pocket, has been with me through the years. She is with me still" (LS19).

Towards the end of the novel Jaya decides to erase the silence between her and Mohan by speaking and listening. This is how she asserts. It is no longer a mute voice, but a voice with hope and promise. The novel ends with a note of optimism. Jaya says, "We don't change overnight. Its possible that we may not change even over long periods of time. But we can always hope. Without that life would be impossible" (LS 193).

Offred's escape along with the underground Mayday resistance group to the underground Female Road to tell her tale is aided by Nick. He is the commander's Chauffer who is the liberating agent of Offred. Nick calls her by her real name and says: "It's May day. go with them' (HT 305). The sign of her identity (real name) is symbolic of breaking the tyranny of silence. She breaks completely the slavery, taking risk as she is " tired of this melodrama. I'm tired of keeping silent" (HT 305).

Thus Offred's narrative stands as a proof that survival is possible through language. For narration confirms existence. The oral element of the narration is emphasized by Atwood through Offred, "It's also a story I'm telling in my head.......Tell rather than write" (HT 306). Narrating her own story validates existence and makes her exist. It is a tale of survival through communication. She articulates silence by carefully selecting symbolic and meaningful names of places, characters and coins new words to signify the ceremonies.

The reminiscences of Jaya evoke a deeper and more tragic sense of vanished time in a calm voice. The experiences become meaningful. The writer distances herself from any intrusion into the psyche of Jaya. Through the sensitive portrayal of the psychic conflicts of Jaya, Shashi Deshpande seems to underline the importance of subverting the established values and replacing them with those values which promote happiness. She neither seeks refuge in an illusionary world nor does she become totally insane, as she has ventilated herself through the process of penning / pinning down her emotions and feelings. 
The Protagonists Break the Tyranny of Silence- A Comparative Study on Margaret Atwood's The Handmaid's Tale and Shashi Deshpande's That Long Silence

Though patriarchy very meticulously schemes to deprive woman of imagination, the power of communication and hope the creative writer helps to articulate woman's silent discourse to decipher the coded language and liberate the imagination of women.

\section{Conclusion}

Shashi Deshpande employs the language of the interior to delineate the inner perception of Jaya who is subtly drawn from inside. She finds her inner routine so disrupted that for the first time in her life she tries to probe into herself to get answers for her existence. Atwood tells the tale with a sense of commitment to expose how dignity and autonomy of women are negated by anarchic and repressive societies like the republic of Gilead. She also suggests the ways and means to surmount the barriers to woman's individuality and autonomy.

\section{REFERENCES}

\section{Primary Sources}

[1] All textual citations in this paper are from this edition of the novel and are followed by page numbers in parentheses (LS) and (HT).

[2] Deshpande, Shashi. That Long Silence, New Delhi: Penguin Books, 1989. Atwood, Margaret. The Handmaid's Tale. London: Vintage, 1996.

\section{Secondary Sources}

[1] Awasthi, A.K., "The Quest for identity in the novels of Shashi Deshapande', Quest for Identity in Indian English Writing Vol. Ed R.S. Pathak, Delhi: Bahri Publications, 1992.

[2] Bhatnagar, K.Manmohan, ed. Feminist English Literature, Delhi Atlantic Publisher, 1999.

[3] Dhawan, R.K. ed. Canadian Literature Today, Delhi: Mehra Press, 1995.

\section{AUTHORS' BIOGRAPHY}

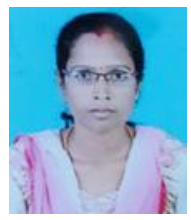

I am S. Sarkunam doing Ph.D. in Part- time under the guidance of Dr.R.C. Sheila Royappa. I am Working as a guest Lecture in Government Arts college, Paramakudi, Ramnad Dist, Tamilnadu. I pursued my MA degree from Dr. Zakir Hussain College, Ilayangudi, Ramnad Dt, TamilNadu and M.Phil form Lady Doak College, Madurai.

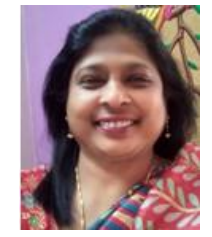

I am Dr. R. C. Sheila Royappa working as a Associate Professor of English at Seethalakshmi Achi College For Women, Pallathur, Sivangangai Dist, TamilNadu. I have been teaching here for last 17 years and having teaching experience of 23 years. I have held many administrative position in additon to my academic career. I am the CoOrdinator of Career Oriented Programme. I have authored for course materials of Alagappa University and Pondicherry University. As a Approved Research Supervisor from Alagappa university I am guiding Mphil and Ph.D. Scholars for the last 5 years. 